\title{
分散制約最適化問題の階層化と分散センサ網にお ける観測資源割り当て問題への適用
}

\section{Layered Distributed Constraint Optimization for Resource Allocation Problem in Distributed Sensor Network}

\author{
$\underset{\text { Kazuhiro Ota }}{\text { 太和宏 }}$ \\ 名古屋工業大学 \\ Nagoya Institute of Technology \\ ohta@matlab.nitech.ac.jp \\ 松井 俊浩
Toshihiro Matsui \\ (同上) \\ matsui.tenitech.ac.jp \\ 松尾 啓志 \\ (同上) \\ matsuoenitech.ac.jp
}

keywords: multi-agent,distributed constraint optimization problem

\begin{abstract}
Summary
Distributed sensor network is an important research area of multi-agent systems. We focus on a type of distributed sensor network systems that cooperatively observe multiple objects using multiple autonomous gaze control sensors. The sensor resource allocation problems of the distributed sensor network can be formalized as distributed constraint optimization problems. However, in the previous works, computation cost to solve the resource allocation problems highly increases with scale/density of the problems. In this work, we divide the problem into two layers of problems. Then two layered cooperative solvers are applied to those problems. Moreover, constraints to keep stability of the allocation in dynamic environment are introduced. The result of the experiment shows that proposed method reduces the number of message cycles. Effects of constraints for the stability of the allocation are also shown.
\end{abstract}

\section{1. は じめに}

マルチェージェントシステムにおける協調問題解決の 基礎的な枠組みとして , 分散制約再適化問題に関する研 究が行われている [Bejar 05, Modi 03a, Modi 05, Zhang 02, 飯塚 07] . 分散制約最適化問題では, エージェントの 意思決定が変数として表現され, 変数間の関係が制約/評 価関数として表現される.エージェントは互いに情報を 交換しつつ自身の変数值を決定し, 制約/評価関数を大域 的に最適化する変数值の割り当てを得る.このような表 現は, 分散システムの協調的な資源スケジューリングの 本質的な問題を表すものとして重要である . また , マル チェージェントシステムの応用分野として分散センサ網 に関する研究も行われており, 弚の資源割り当て問題を 分散制約最適化問題として形式化する手法も研究されて いる [Bejar 05, Modi 03a] . 分散センサ網には広域の観測 情報の収集など樣々な目的があるが，特に本論文では視 野制御可能な自律的なセンサ群による観測システムを想 定する . 複数の対象を複数のセンサにより注視するため の制御は, 観測資源の割り当て問題として捉えることが 出来る. 実際的な観測システムでは観測対象が移動する など，環境は動的に変化する．このような動的な環境へ
の追従は, 環境の変化を表す時系列的な割り当て問題を 反復的に解くこととして捉えることが出来る. 兴の一方 で，ある時刻の問題に対して割ける時間は限られており， 解を短時間に得る必要がある. 光のため比較的短時間に 非厳密解を得ることが可能な確率的な解法を用いること が有用であるといえる .このような観測資源の割り当て 問題においては, 各エージェントが矛盾無く意思決定を 行う必要がある．しかし，エージェントの協調と観測資 源割り当てを含む問題は複杂倠であり，探索に要する時間 の抑制には課題がある .

従来研究 [Matsui 10] では観測資源割り当て問題が， エージェンシの枠組みを用いた分散協調カメラ網 [浮田 05]に類似する，階層構造を持つ分散制約最適化問題と して形式化されている．また，初期の検討として，簡易 な貪欲的解法によって問題を解く場合の探索の過程の一 例が示され，局所解への収束が問題となりうることが示 されている.しかし，より具体的な解法の適用について の検討は今後の課題とされている .このような問題に対 する解法は, 局所解からの脱出が可能な解探索を必要と する . さらに解法を階層構造を持つ問題に適応させるこ とや，環境の観測から問題の生成までの前処理と統合す 
ることが必要である．より実際的な拡張として，時系列 的な变化を伴う問題への適応も望まれる.

本論文では従来研究のアイデアを基に，センサ資源割 り当て問題を階層構造を持つ問題として形式化し, 分散 制約最適化問題の確率的解法を適用する手法を提案する . さらに, 時系列的な変化を伴う動的な問題への拡張を提 案する.この拡張のために観測資源の割り当ての変化を 抑制する制約が導入される．解法においては，リーダー 選出問題の階層と資源割り当て問題の階層产れ光れで確 率的探索を行い，2つの階層の探索処理を協調的に動作 させる．これにより問題の複雑さを抑制し解探索時間を 削減する効果が得られる．また，動的に変化する環境の 観測から問題の生成と解探索にいたるまでの一連の処理 を，分散アルゴリズムの枠組みに統合する．

以降，第 2 章で分散制約最適化問題について説明し， 第 3 章で分散センサ網の観測資源割り当て問題について 説明する. また従来研究で提案された分散制約最適化問 題による形式化とエージェンシに基く協調モデルについ て説明する.第 4 章及び第 5 章で提案手法について説明 する．乥して，第 6 章で評価を行う。

\section{2. 分散制約最適化問題 (DCOP)}

本章では分散制約最適化問題の基本的な形式化と，光 の解法について説明する .

\section{$2 \cdot 1$ 形 式 化}

分散制約最適化問題 (DCOP) は複数のエージェント で構成される. 各エージェント $a_{i}$ は変数の集合 $X_{i}=$ $\left\{x_{i}^{1}, \ldots, x_{i}^{k}\right\}$ を持ち, 光れ光れの変数は離散的で有限な 值の集合 $D_{i}^{k}$ に含まれる值をとる . エージェント $a_{i}$ は $X_{i}$ に含まれる变数の值のみ決定出来る.つまり，变数は エージェントの意思決定を表す. 変数間の関係は制約 $c$ によって表現される.制約 $c$ に関する評価関数 $f_{c}$ は变数 值の組み合わせについてのコスト值を定義する . 本論文 の形式化では，制約は緩和可能な制約と緩和不可能な制 約に分類される . 問題の目的は , 緩和することが不可能 な制約を充足し，緩和することが可能な制約を可能な限 り満足する变数值の組合せを決定することである.特に， 緩和不可能な制約は全て充足しているが，緩和可能な制 約の一部は満たされていない解を準最適解と呼ぶことに する .

\section{$2 \cdot 2$ 解 法}

DCOP を解く厳密解法として ADOPT[Modi 05, Modi 03b, Ali 05] や DPOP[Petcu 05] が提案されている.こ れらの解法は制約網に対する深さ優先探索木に基づく . ADOPT は分枝限定法/A*による探索を行う. DPOP は 動的計画法に基づく . これらの解法の問題点は探索木の induced-width[Petcu 05] に従って探索時間，もしくは記

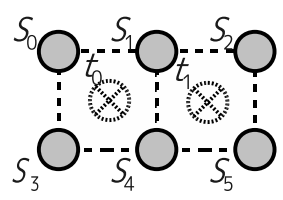

図 1 グリッドモデルでの表現

憶領域が指数関数的に増加する点である . induced-width が大きい場合は, メモリ量や探索時間の制限のために , 厳 密解法を適用することには課題がある .

兴の一方で, 比較的短時間で非厳密解を得ることが可 能な確率的解法として DSA[Zhang 02]やDSTS[飯塚 07] が提案されている．本論文で想定する準実時間性を要す るシステムでは，解を得るまでの時間の観点から，確率 的解法が有用であると考えられる.乥こで, 分散センサ網 の観測資源割り当て問題の解法としてDSTS を適用する .

DSTS は確率的な反復改善型アルゴリズムである DSA に，局所解からの脱出を目的として，タブー探索を組み 込んだアルゴリズムである . DSTS では各ェージェント が互いの変数值を交換しつつ解を求める. 各ェージェン 卜は制約で関係するエージェントの変数值に基き，自身 の各変数值に対するコスト值を計算する . 光して，コス 卜值を最も改善する变数值が候補として選ばれる.エー ジェントの変数值は, 確率 $p_{1}$ に従って候補の值に変更さ れる. また, 変数值を変更する際に, 以前の変数值の履 歴をタブーリストに追加し，一定期間 (TABU 期間) 光の 值への遷移を禁止する .タブー探索のために , コスト值 の改善量が負となる変数值しか選択出来ない可能性もあ る. 弚の場合，自身の制約が満たされていなければ，確 率 $p_{2}$ に従って変数值を変更する. これらの処理て変数值 が更新された場合, 自身の变数に関するメッセージを生 成し，制約で関係するセンサに送信する。

\section{3. 分散センサ網における資源割り当て問題}

本章では, 分散センサ網の観測資源割り当て問題を形 式化する．また, 関連研究について述べる.

\section{$3 \cdot 1$ グリッドモデル}

本論文では観測資源を観測対象に割り当てる観測資源 割り当て問題の基礎的な表現として，センサがグリッド 状に配置されたモデルを用いる .このようなモデルは関 連研究でも用いられている [Bejar 05, Modi 03a] . 本論文 では，この樣なモデルをグリッドモデルと表記する．本 論文て想定するシステムでは，制御の対象はセンサのみ である . ぞのため, センサをエージェントとみなす．図 1 では $s_{i}$ がセンサを示し， $t_{j}$ が観測対象を示す．また， 各区画に 1 個の観測対象しか存在できないものとした .

センサの視野には制限がある.この制限は緩和出来な い.ここでは, センサは隣接する区画のみ観測可能とし 


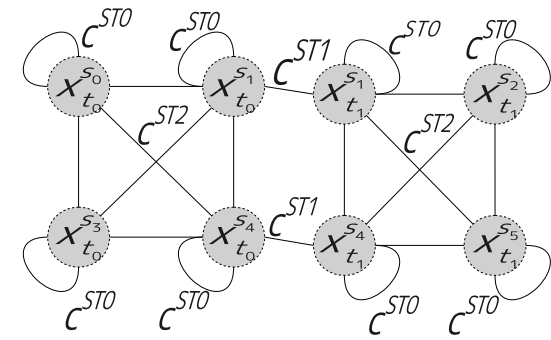

図 2 STAV による制約網の表現

た .また，各センサは同時に多数の対象物を注視出来な い.ここでは, 1 個のセンサは同時に 1 個の観測対象に のみ割り当てられるものした . 兴の一方で, 観測により 得られる情報量を向上するためには, 各観測対象を複数 のセンサで観測することか望ましい場合がある．ここで は, 1 個の観測対象に可能な限り 3 個のセンサを割り当 てるものとした .この目的は緩和可能であり，3 個未満 のセンサで観測することも許容される .

\section{$3 \cdot 2$ DCOP に基づく 形式化}

分散センサ網における観測資源割り当て問題のための， DCOP に基づく形式化について説明する .ここでは従来 の形式化として STAV(Sensor-TargetAsVariable) を示す . STAV ではセンサと観測対象の組か変数として定義され る. 各センサは観測することが可能な観測対象の数だけ 変数を持つ.これと類似する表現は文献 [Modi 03a] で用 いられている.図 1 の配置の制約網をSTAV を用いて表 現すると図 2 のようになる.図 2 の $x_{t_{j}}^{s_{i}}$ はセンサ $s_{i}$ が持 つ観測対象 $t_{j}$ についての変数を表す . $x_{t_{j}}^{s_{i}}$ の值はどのセ ンサか観測対象 $t_{j}$ に割り当てられているかを示し， $t_{j}$ を 観測可能なセンサの組み合わせを表す変数值をとる . 観 測可能なセンサの集合が $\left\{s_{0}, \cdots, s_{n}\right\}$ ならば, 変数 $x_{t_{j}}^{s_{i}}$ の 変域は $\left\{\phi,\left\{s_{0}\right\}, \cdots,\left\{s_{n}\right\},\left\{s_{0}, s_{1}\right\}, \cdots,\left\{s_{0}, \cdots, s_{n}\right\}\right\}$ と 表される.この表現では図 2 の $c^{S T 0}, c^{S T 1}, c^{S T 2}$ で示さ れる 3 種類の制約を用いる .

\section{- $c^{S T 0}\left(x_{t_{j}}^{s_{i}}\right)$ :観測資源割り当てに関する制約}

各観測対象に可能な限り 3 個のセンサを割り当てる ための制約である . 観測対象 $t_{j}$ に割り当てられたセ ンサの数が 3 個に満たない場合に違反となる.この 制約は緩和可能である.制約 $c^{S T 0}$ に対する評価関 数 $f_{c^{S T 0}}$ は式 (1)で表現される.ただし $w^{c^{S T 0}}$ は制 約のコスト值を示す定数値である．また， $n_{j}$ は観測 対象 $t_{j}$ に割り当てられたセンサの数を示す.

$$
f_{c^{S T 0}\left(x_{t_{j}}^{s_{i}}\right)}=\left\{\begin{array}{lr}
w_{n_{j}}^{c^{S T 0}} & n_{j}=0,1,2 \\
0 & \text { otherwise }
\end{array}\right.
$$

- $c^{S T 1}\left(x_{t_{j}}^{s_{i}}, x_{t_{j^{\prime}}}^{s_{i}}\right)$ :観測資源の制限に関する制約 各センサが同時に複数の観測対象に割当てられるこ とを制限するための制約である．1 個のセンサが同 時に 2 個以上の観測対象に割り当てられる場合に違

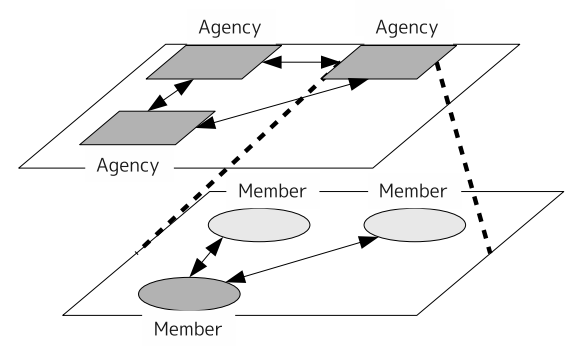

図 3 エージェンシによる協調モデル

反となる.この制約は緩和不可能である.制約 $c^{S T 1}$ に対する評価関数 $f_{c S T 1}$ は式 (2) で表現される.た だし $w^{c^{S T 1}}$ は制約のコスト値を示す定数值である.

$f_{C^{S T 1}\left(x_{t_{j}}^{s_{i}}, x_{t_{j^{\prime}}}^{s_{i}}\right)}= \begin{cases}w^{c^{S T 1}} & x_{t_{j}}^{s_{i}} \cap x_{t_{j^{\prime}}}^{s_{i}} \neq \phi \\ 0 & \text { otherwise }\end{cases}$

- $c^{S T 2}\left(x_{t_{j}}^{s_{i}}, x_{t_{j}}^{s_{i^{\prime}}}\right)$ :変数值の整合性に関する制約

同じ観測対象を観測することが可能なセンサが協調 するための制約である . 同じ観測対象に対するセン サの割り当ての組み合わせがセンサ間で異なる場合 に違反となる .この制約は緩和不可能である.制約 $c^{S T 2}$ に対する評価関数 $f_{c} S T 2$ は式 (3) のように表さ れる.ただし $w^{c^{S T 2}}$ は制約のコスト值を示す定数值 である

$f_{c^{S T 2}\left(x_{t_{j}}^{s_{i}}, x_{t_{j}}^{s_{i^{\prime}}}\right)}= \begin{cases}w^{c^{S T 2}} & x_{t_{j}}^{s_{i}} \neq x_{t_{j}}^{s_{i^{\prime}}} \\ 0 & \text { otherwise }\end{cases}$

\section{$3 \cdot 3$ エージェンシによる協調モデル}

分散制約最適化問題と異なる枠組みとして，センサのグ ループであるェージェンシを用いた分散協調処理による 観測システム [浮田 05] ガ提案されている.エージェンシ による協調モデルの概念図を図 3 に示す .このシステムは 視野制御可能なカメラセンサ (AVA: ActiveVisionAgent) と観測対象からなり，本論文で想定するシステムの条件 と同じである .このシステムの概要は次の通りである .

-AVA は観測対象を検出すると，同一観測対象毎に エージェンシを作成する．

・各エージェンシには代表の AVA(マネージャ)が 1 個 存在する . 他の AVA はマネージャの意思決定に従う .

・各マネージャは互いに情報を交換し，観測資源の配 分を決定する.

・観測対象の情報は各マネージャに集約される .

このシステムは実機を用いた実験環境で有効性が実証さ れている .このような階層的な協調の構造は有効である と考えられる．しかし，この手法では DCOP のような 最適化問題としての問題表現と弚の解法は用いられてい ない。 


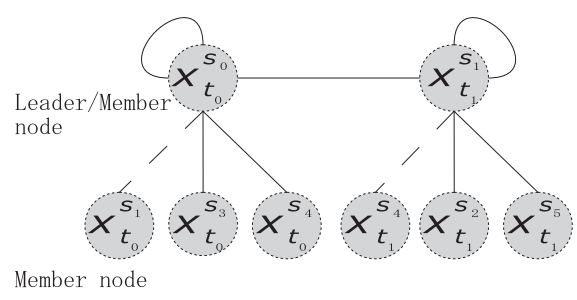

図 4 階層構造を考慮した制約による形式化

\section{4 階層構造を考慮した制約による形式化}

制約網による形式化に，エージェンシによる協調モデ ルの持つ階層的な構造を導入することで, 制約網による 柔軟な問題の記述と，階層構造による効率的な協調動作 を統合できると考えられる .このような形式化のアイデ アは, 関連研究 [Matsui 10] に示されている. 図 1 の問題 に対する，階層的な制約網の概要を图 4 に示す. 各ノー ド $x_{t_{j}}^{s_{i}}$ は, センサ $s_{i}$ が知る対象物 $t_{j}$ へのセンサの割り当 てを表す . 図の例では，観測対象 $t_{0}, t_{1}$ ごとにリーダー と光の配下のメンバからなるグループか構成されている . $t_{0}, t_{1}$ 光れ光れのリーダーは観測資源の割り当てに関す る制約で関係する．乥れ以外のメンバはリーダーの意思 決定に従う $. s_{1}, s_{4}$ は乥れ光れ， $t_{0}, t_{1}$ の両方を観測でき るため, いずれのグループのメンバにもなりうるが , 実 線で接続されているリーダーに従う．このような階層構 造を形成するためには，本来の資源割り当て問題に加え て, 先ず観測対象ごとにリーダを決定しグループを形成 する問題を解く必要がある.関連研究ではこのような問 題について，制約最適化問題としての形式化が検討され ている．また，初期の検討として，簡易な貪欲的解法に よって問題を解く場合の探索の過程の一例が示され，局 所解への収束が問題となりうることが示されている．し かし, より具体的な解法の適用についての検討は今後の 課題とされている.

このような問題に対する解法は局所解からの脱出が可 能な解探索を必要とする.また, 弚の解法を階層構造を 持つ問題に適応させることや，環境の観測から問題の生 成までの前処理との統合も必要である.さらに実際的な 拡張として, 時系列的な変化を伴う問題への適応も望ま れる。

\section{2 つの階層からなる形式化}

前述のように，制約網による形式化にエージェンシによ る協調モデルの持つ階層的な構造を導入することで, 制 約網による柔軟な問題の記述と，階層構造による効率的 な協調動作を統合できると考えられる、本節では，この 樣な形式化にもとづく解法を提案する．すなわち，リー ダ一選出層と資源割り当て問題解決層の 2 つ階層に問 題を分割し，各階層にDCOP の確率的解法を適用する. 本研究の階層化のアイデアは従来研究 [Matsui 10] を基
礎とするが, 形式化の方針には差異がある . 従来研究で は,階層化のアイデアを簡潔に表現することを意図し，比 較的トップダウンすなわちリーダーの視点寄りの形式化 を用いているが，光の形式化を管理する処理か制約最適 化手法に組み込まれることが想定されていると考えられ る. 本研究の形式化はエージェント間の協調の形式的な 記述を重視し，STAVに上位の階層を設けつつ，光の状 態空間と制約を改良してて長性を削減したものとなって いる.これは, STAV との比較の上でも有用であると考 えられる。

\section{$4 \cdot 1$ リーダー選出層}

リーダー選出層では, 各観測対象に対して 1 個のセン サをリーダーとして選出する.これはエージェンシによ る協調モデルにおいて, 各観測対象に対して 1 個のエー ジェンシを生成することに相当する。

エージェントは観測対象ごとのグループに分けられる . グループとはリーダーと,リーダーが担当する観測対象に 割り当られたセンサからなる.リーダーは, 同じグルー プに属するセンサの観測対象への割り当てを決定する したがって，観測対象を観測することが可能なセンサの いずれかがリーダーとなることが妥当である．また，後 述の資源割り当て問題解決層の探索空間を削減するため に，観測対象 $t_{j}$ のリーダーは必ず観測対象 $t_{j}$ に割り当 てることにする ．

図 1 の配置の場合，リーダー選出層の制約網は図 5(a) のように表現される . 図 $5(\mathrm{a})$ の $x_{t_{j}}^{s_{i}}$ は, センサ $s_{i}$ が持 つ, 観測対象 $t_{j}$ についての変数である.$x_{t_{j}}^{s_{i}}$ の值は, 観 測対象 $t_{j}$ のリーダーを示す . $t_{j}$ を観測可能なセンサの集 合が $\left\{s_{0}, \cdots, s_{n}\right\}$ ならば, $x_{t_{j}}^{s_{i}}$ は $\left\{\phi, s_{0}, \cdots, s_{n}\right\}$ のいず れかを表す変数值をとる.リーダー選出層では図 5(a)の $c^{L 0}, c^{L 1}, c^{L 2}, c^{L 3}$ で示される4 種類の制約を用いる .

- $c^{L 0}\left(x_{t_{j}}^{s_{i}}\right):$ リリーダーの選出に関する制約

各観測対象へ 1 個のセンサをリーダーとして選出す るための制約である . 観測対象 $t_{j}$ に対してリーダー が選出されていない場合に違反となる .この制約は 緩和可能である. 制約 $c^{L 0}$ に対する評価関数 $f_{c^{L 0}}$ は 式(4)のように表される.ただし $w^{c^{L 0}}$ は制約のコス 卜値を示す定数值である.

$f_{c^{L 0}\left(x_{t_{j}}^{s_{i}}\right)}= \begin{cases}w^{c^{L 0}} & x_{t_{j}}^{s_{i}}=\phi \\ 0 & \text { otherwise }\end{cases}$

- $c^{L 1}\left(x_{t_{j}}^{s_{i}}, x_{t_{j^{\prime}}}^{s_{i}}\right):$ リーダーであるセンサの観測資源の制 限に関する制約

各センサが同時に複数の観測対象のリーダーに選出 されることを制限するための制約である．1 個のセ ンサが同時に 2 個以上の観測対象のリーダーに選出 される場合に違反となる .この制約は緩和不可能で ある.制約 $c^{L 1}$ に対する評価関数 $f_{c^{L 1}}$ は式 (5)のよ 
うに表される・ただし $w^{c^{L 1}}$ は制約のコスト値を示 す定数值である .

$f_{c^{L 1}\left(x_{t_{j}}^{s_{i}}, x_{t_{j^{\prime}}}^{s_{i}}\right)}= \begin{cases}w^{c^{L 1}} & x_{t_{j}}^{s_{i}}=x_{t_{j^{\prime}}}^{s_{i}} \\ 0 & \text { otherwise }\end{cases}$

- $c^{L 2}\left(x_{t_{j}}^{s_{i}}, x_{t_{j}}^{s_{i^{\prime}}}\right):$ リーダーの整合性に関する制約

同一の観測対象を観測可能なセンサが協調するため の制約である.リーダー選出層における同一の観測 対象に関する変数の值が, センサ間で異る場合に違 反となる．この制約は緩和不可能である.制約 $c^{L 2}$ に対する評価関数 $f_{c L 2}$ は式 (6)のように表される. ただし $w^{c^{L 2}}$ は制約のコスト值を示す定数值である.

$f_{c^{L 2}\left(x_{t_{j}}^{s_{i}}, x_{t_{j}}^{s_{i^{\prime}}}\right)}= \begin{cases}w^{c^{L 2}} & x_{t_{j}}^{s_{i}} \neq x_{t_{j}}^{s_{i^{\prime}}} \\ 0 & \text { otherwise }\end{cases}$

- $c^{L 3}\left(x_{t_{j}}^{s_{i}}\right):$ リーーダーの配置に関する制約

各観測対象に割り当てることが可能なセンサの数が 十分となるように,リーダーを選出するための制約 である.リーダーは必ず担当の観測対象に割り当て られるため, 他の観測対象に割り当て可能なセンサ の集合から除外される.弚のため, 観測対象に 3 個の センサを割り当てられなくなる状況に陥る可能性が ある.この樣な状況を避けるために，観測可能な観 測対象の数が少ないセンサを, 可能な限りリーダー として選出する.この制約は観測可能な観測対象が 一番少ないセンサ以外をリーダーに選出した場合に 違反となる.この制約は緩和可能である.制約 $c^{L 3}$ に対する評価関数 $f_{c L 3}$ は式 (7) のように表される. ただし $w^{c^{L 3}}$ は制約のコスト值を示す定数值である． また， $S_{t_{j}}$ は観測対象 $t_{j}$ を観測することが可能なセ ンサの集合を示し,$v_{i}$ はセンサ $s_{i}$ か観測可能な観測 対象数を示す.

$f_{c^{L 3}\left(x_{t_{j}}^{s^{i}}\right)}= \begin{cases}w^{c^{L 3}} & \exists s_{i} \in S_{t_{j}}, v_{i}<v_{x_{t_{j}}^{s^{i}}} \\ 0 & \text { otherwise }\end{cases}$

リーダー選出層では变数の数は STAV を用いる手法と同 じであり，制約数はより多い，光の一方で，リーダー選 出層の方が各変数の変域が小さいため, 問題を比較的容 易に解くことが出来ると考えられる．

\section{2 資源割り当て問題解決層}

資源割り当て問題解決層では, リーダー選出層で選出 されたリーダーが, 観測対象へのセンサの割り当てを 解決する. 各リーダーは互いに情報を交換して問題を 解き，リーダー以外のセンサはリーダーの決定に従う． リーダー選出層では各観測対象に 1 個のリーダーが選 出されるため, 図 1 のような配置の場合, 制約網は図 5(b)のように表現される . 図 5(b) において $x_{t_{j}}$ は観測対 象 $t_{j}$ のリーダーに選出されたセンサが持つ変数である $x_{t_{j}}$ の值は, 観測対象 $t_{j}$ にどのセンサか割り当てられる

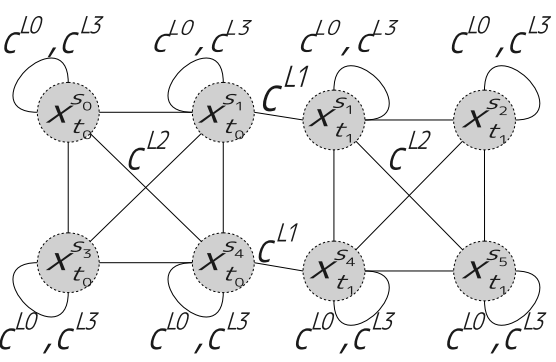

(a)リーダー選出層

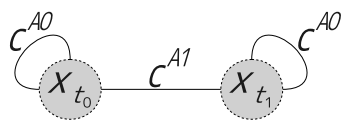

(b)資源割り当て問題解決層

図 5 提案手法における制約網

かを示す.$t_{j}$ を観測可能なセンサの集合が $\left\{s_{0}, \cdots, s_{n}\right\}$ ならば， $x_{t_{j}}$ は観測することが可能なセンサの組み合わ せ $\left\{\phi,\left\{s_{0}\right\}, \cdots,\left\{s_{n}\right\},\left\{s_{0}, s_{1}\right\}, \cdots,\left\{s_{0}, \cdots, s_{n}\right\}\right\}$ を表す 変数值をとる.ただし，観測対象 $t_{j}$ のリーダーは $t_{j}$ に 必ず割り当てられるため, 組み合わせからは除外される . 資源割り当て問題解決層では, 图 5(b) の $c^{A 0}, c^{A 1}$ で示さ れる 2 種類の制約を用いる.

- $c^{A 0}\left(x_{t_{j}}\right)$ :観測資源割り当ての要求に関する制約

観測対象への観測資源割り当ての要求に関する制約 である.観測対象 $t_{j}$ に割り当てられたセンサの数が 3 個に満たない場合に違反となる.この制約は緩和可 能である.制約 $c^{A 0}$ に対する評価関数 $f_{c^{A 0}}$ は式 (8) のように表される.ただし $w^{c^{A 0}}$ は制約のコスト值 を示す定数值である.また $n_{j}$ は観測対象 $t_{j}$ に割り 当てられたセンサの数を示す.

$f_{c^{A 0}\left(x_{t_{j}}\right)}= \begin{cases}w_{n_{j}}^{c^{A 0}} & n_{j}=0,1,2 \\ 0 & \text { otherwise }\end{cases}$

- $c^{A 1}\left(x_{t_{j}}, x_{t_{j^{\prime}}}\right)$ :観測資源の制限に関する制約

各センサが同時に複数の観測対象に割り当てられる ことを制限するための制約である．1個のセンサが同 時に 2 個以上の観測対象に割り当てられる場合に違 反となる．この制約は緩和不可能である.制約 $c^{A 1}$ に対する評価関数 $f_{c^{A 1}}$ は式 (9) のように表される . ただし $w^{c^{A 1}}$ は制約のコスト值を示す定数值である.

$f_{c^{A 1}\left(x_{t_{j}}, x_{t_{j^{\prime}}}\right)}= \begin{cases}w^{c^{A 1}} & x_{t_{j}} \cap x_{t_{j^{\prime}}} \neq \phi \\ 0 & \text { otherwise }\end{cases}$

資源割り当て問題解決層の問題の表現では, 変数と制約 の数がSTAV よりも少ない．また，観測対象 $t_{j}$ に関する リーダーは必ず観測対象 $t_{j}$ に割り当てられるため,さら に変数の值域か制限される.この 2 点から，資源割り当 て問題解決層の問題は STAV よりも容易に解くことが出 来ると考えられる . 


\section{$4 \cdot 3$ 解 法}

階層化された形式化に基づく解法の概念図を図 6 に示 す. 2 つの階層には，光れ独立したDCOPの解法を 適用する. 弚れ光れの階層の解法では, 自身の变数值と 制約で関係するセンサから送られてきた変数值に基いて， 独立に問題を解く (図 6 の a, b) . 資源割り当て問題解決 層の変数は, リーダー選出層の変数の情報を基に作成さ れる(図 6 の) .

センサ $s_{i}$ を主体として，解法の擬似コードを図 7 に示 す. 図 7 の my_status はセンサ $s_{i}$ がリーダーであるか否 か表す真偽値を取る．また，leader_listはリーダーである センサのリストである

資源割り当て問題解決層では, リーダー選出層の解に 基づく問題を解かなければならない，弚の一方で各リー ダーが自身に関係する問題を解くためには，資源割り当 て問題解決層において制約で関係する他のリーダーの変 数值を得ればよい，光こで，各センサは自身がリーダー に選出されたと判断したとき, 資源割り当て問題解決層 において制約で関係する可能性のあるセンサにリーダー であることを通知する .これにより資源割り当て問題解 決層の処理を部分的に開始できる。

各センサは次の 2 つの条件が共に満足されたとき，自 身がリーダーに選出されたと判断する．

・リーダ選出層における変数值が, 自身がいずれかの 観測対象のリーダーであることを表している．セン サ $s_{i}$ が観測可能な観測対象の集合を $T_{s_{i}}$ とすると， 式 (10)のように表すことが出来る .

$l_{1}= \begin{cases}\text { true } & \exists t_{j} \in T_{s_{i}}, x_{t_{j}}^{s_{i}}=s_{i} \\ \text { false } & \text { otherwise }\end{cases}$

・リーダー選出層において自身か関係する，緩和不可 能な制約がすべて満たされている.緩和不可能な制 約の集合を $C$ とすると，式(11)のように表すこと が出来る.

$l_{2}= \begin{cases}\text { true } & \forall c \in C, f_{c}=0 \\ \text { false } & \text { otherwise }\end{cases}$

すなわち，あるセンサがリーダー選出層においてリーダー として割り当てられた状態であっても，他の緩和不可能 な制約を満たさない場合は，資源割り当て問題解決層で は弚のセンサをリーダーとして扱わない .

$l_{1} \wedge l_{2}=$ true であれば，センサ $s_{i}$ は自身がリーダー であると判断する．乥して，図 7 中 14-18 行目に示す処 理で，自身がリーダーであることを通知するメッセージ is_leader を生成する .ここでis_leader の宛先のセンサ の集合を $S_{a}$ とする.$S_{a}$ は， $s_{i}$ がリーダとなった観測対 象を観測可能なセンサの一部からなる集合であり，次の ように表される。

観測対象 $t_{j}$ に割り当て可能なセンサの集合を $S_{t_{j}}$, 光 れ以外の観測対象 $t_{j^{\prime}}$ に割り当て可能なセンサの集合を

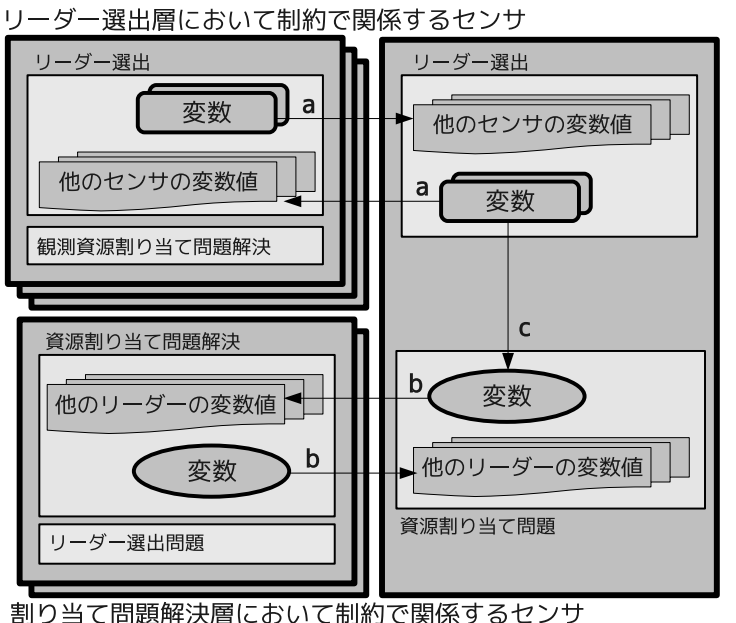

図 6 階層化による形式化の概念図

$S_{t_{j^{\prime}}}$ とする . 観測対象 $t_{j}$ のリーダーに選出されたセンサ $s_{i}$ がリーダーであることを通知するセンサの集合 $S_{a}$ は， $S_{t_{j}} \cap S_{t_{j^{\prime}}} \neq \phi$ を満たす観測対象 $t_{j^{\prime}}$ を観測可能なセンサ からなる.グリッドモデルにおいて $S_{a}$ に含まれる可能 性のあるセンサは, グリッド上で近傍のセンサと, 近傍 のセンサのさらに近傍のセンサである . 兴のため , メッ セージis_leader はまずグリッド上で近接するセンサに 送信される .メッセージis_leader を受信したセンサは， 図 7 の 6-8 行目に示される処理でメッセージを複製し， さらに近接するセンサに伝搬する．なお， $t_{j}$ のみに割り 当て可能なセンサには, is_leader を伝達せずとも制約に よって割り当てが整合する.

リーダー選出層における解探索が大域的に収束するま では, 未収束部分の探索の影響により, 既にリーダーと 判断していたセンサが兴の条件を満たさなくなることが ある . このとき，図 7 の 19-23 行目に示される処理で， メッセージ not_leader を生成し， $S_{a}$ に含まれるセンサ に送信する．このメッセージは自身がリーダーでなくなっ たことを通知する . not_leader を受信したセンサは, 图 7 の 9-11 行目に示される処理で, メッセージを複製しグ リッド上で近接するセンサに伝搬する .

図 7 の $V$ は 2 つの階層における变数の集合を示す. is_leader,not_leader 及び変数は図 7 の 27 行目における 処理で一括して送信される.

\section{5. 動的な問題への対応}

階層化された構造を持つDCOP の表現は, エージェン トのグループの形成とグループ間での交渉を, DCOP の 枠組みに導入することを意图する。観測対象 $t_{j}$ に関す るグループのリーダーには, $t_{j}$ に割り当て可能なセンサ がどの観測対象に割り当てられるかという情報が集約さ れる . この情報は, 問題が変化する場合の解法で利用さ れる。 


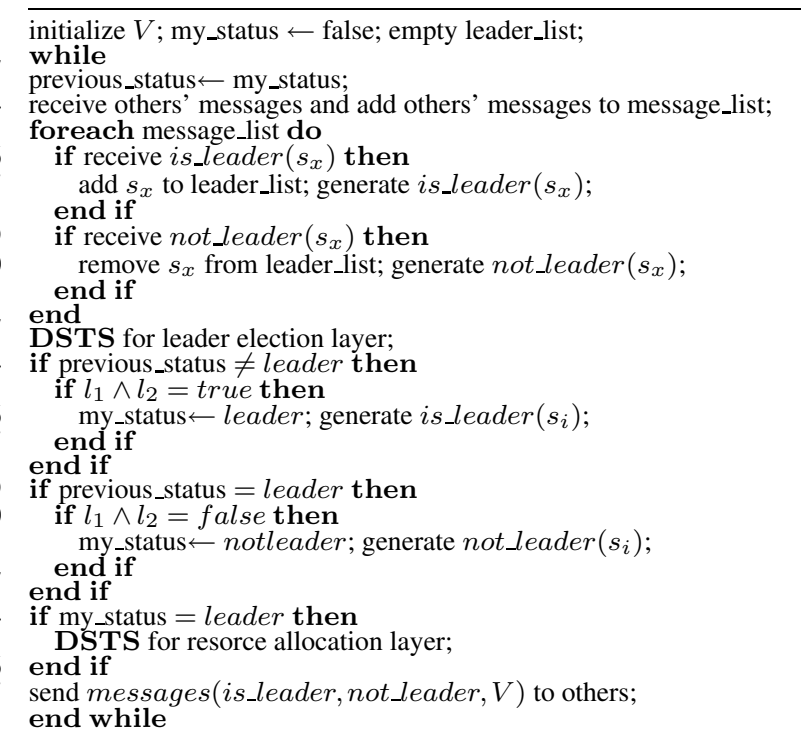

図 7 2 つの階層からなる形式化を用いた場合の解法

本研究で想定するシステムでは, センサの視野の方向 の制御などの観点から，観測対象の配置か湾化した際に， センサの割り当てか瀕繁に変化することは望ましくない． 乥こで, 観測対象へのセンサの割り当ての変化を抑制す るための制約を導入する．关の基礎としてセンサの割り 当てに関する状態を定義し，状態を計算する前処理を用 いる。

センサの割り当ての状態は観測対象ごとに表として管 理される.この情報を用いて割り当ての変化を抑制する 制約が定義される．以下では必要に応じて，観測対象の 配置が変化する前の状況を問題変化前と表記し, 変化し た後の状況を問題変化後と表記する．

\section{$5 \cdot 1$ センサの割り当ての状態}

観測対象の配置が変化したときに, センサの割り当て の変化を抑制するためには, 各センサがどの観測対象に 割り当てられているかという情報が必要である. 乥こで， 資源割り当て問題解決層において観測対象 $t_{j}$ に割り当て 可能なセンサの状態を次のように分類する .

・ $t_{j}$ member: $t_{j}$ に関するグループに属するセンサ

• Other_member: $t_{j}$ 以外のグループに属するセンサ

・ New: $t_{j}$ に新しく割り当てることが可能になったセ ンサ

• Free: 上記以外のセンサ .

この分類は, 観測対象 $t_{j}$ に関するグループと, 観測対象 $t_{j}$ に割り当て可能なセンサの関係を表す .ここで, 観測 対象 $t_{j}$ に関するグループとは, 観測対象 $t_{j}$ に関するリー ダーと観測対象 $t_{j}$ に割り当てられたセンサの集合である

観測対象 $t_{j}$ 以外の観測対象にも割り当て可能なセン サは, 他方の観測対象については異なる状態を取ること がある . 例えば，観測対象 $t_{j}$ に関する割り当ての状態が

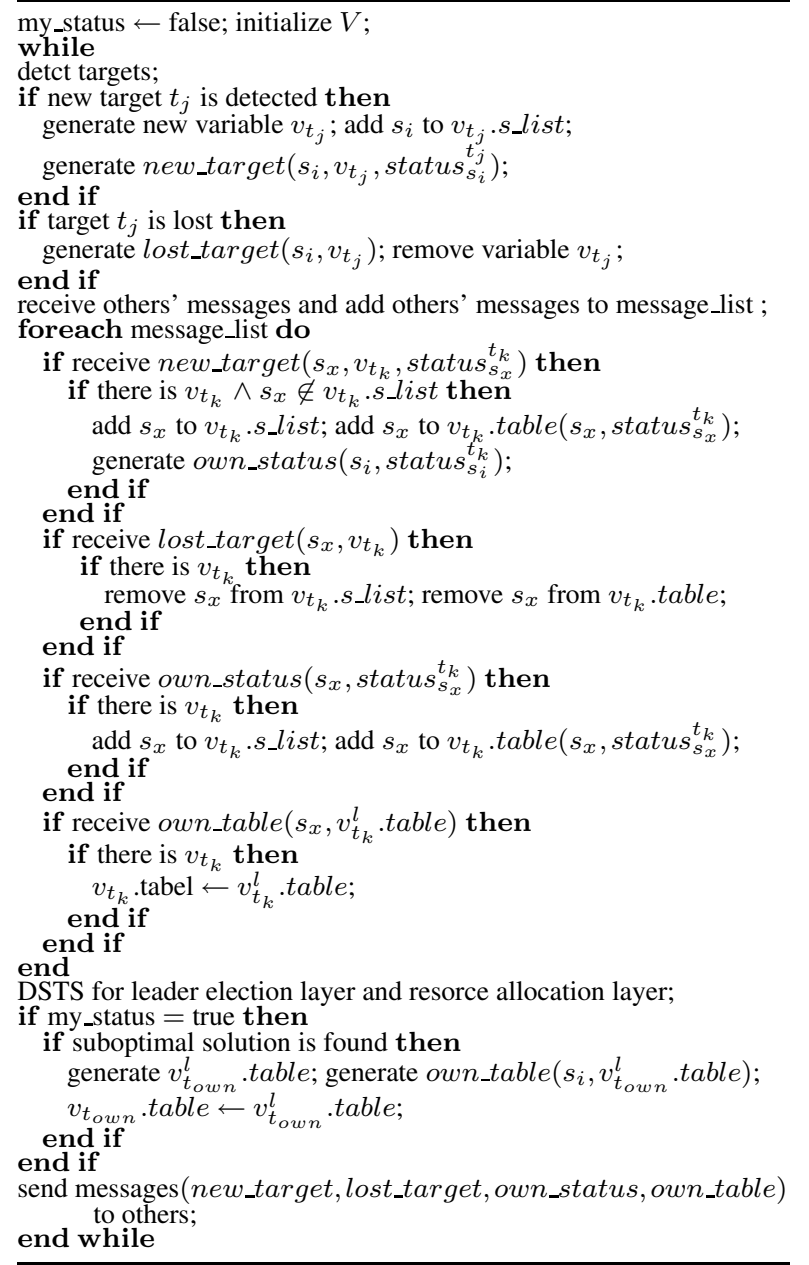

図 8 問題か湾化した際の通知に関する擬似コード

$t_{j}$ _member であるセンサは, 弚れ以外の観測対象につい ては割り当ての状態が Other_member となる .

\section{$5 \cdot 2$ 変数の生成·削除, 表の生成}

観測対象の配置が変化し，センサが観測できる観測対 象が变化したとき，リーダー選出層において制約で関係 する可能性のあるセンサ間で, 変数の生成, 削除および 通知が行われる .これにより，センサの割り当て状態の表 が生成される．センサ $s_{i}$ を主体として，この処理の擬似 コードを図 8 に示す.图 8 において $V$ はセンサ $s_{i}$ が持 つリーダー選出層における変数の集合を示す．疑似コー ド中では $V$ は暗黙的に用いられる . my_status はセンサ $s_{i}$ がリーダーであるか否かを表す真偽值を取る.$v_{t_{j}}$ は リーダー選出層における観測対象 $t_{j}$ に関する変数である. $v_{t_{\text {own }}}^{l}$ は観測対象 $t_{\text {own }}$ のリーダーが持つ割り当て問題解 決層における变数である. $v_{t_{j}} . s_{-}$list は観測対象 $t_{j}$ に割 り当てることが可能なセンサの集合を表す . $v_{t_{j}}$. table は 観測対象 $t_{j}$ に関するセンサの割り当て状態の表である . $v_{t_{j}}$.table を状態表と呼ぶ . 


\section{$\S 1$ 変数の生成· 削除}

センサ $s_{i}$ が新たに観測対象 $t_{j}$ を観測することが可能 になったとき，図 8の 4-7 行目に示される処理で，観測 対象 $t_{j}$ に関する変数を生成し,さらに観測対象 $t_{j}$ に関 するメッセージnew_target を生成する .このメッセー ジには, 観測対象 $t_{j}$ に関する変数と, 観測対象 $t_{j}$ につ いてのセンサ $s_{i}$ の状態が含まれる .ここで, new_target の宛先のセンサの集合を $S_{l}$ とする.$S_{l}$ は, 観測対象 $t_{j}$ に関する変数について,リーダー選出層において制約で 関係する可能性があるセンサの集合であり，次のように 表される．

観測対象 $t_{j}$ に関する変数を生成したセンサ $s_{i}$ が観測 することが可能な領域の集合を $A_{s_{i}}$ とする．また，乥れ 以外のセンサ $s_{x}$ が観測することが可能な領域の集合を $A_{s_{x}}$ とする.このとき, $A_{s_{i}} \cap A_{s_{x}} \neq \phi$ を満たすセンサ $s_{x}$ が $S_{l}$ に含まれる.グリッドモデルでは,$S_{l}$ に含まれ るセンサはグリッド上でセンサ $s_{i}$ の近傍であるセンサで ある

観測対象 $t_{k}$ に関する new_target を受信したセンサ $s_{i}$ は , 図 8の13-18 行目に示されるように次の処理を行う . $s_{i}$ 自身か観測対象 $t_{k}$ に関する変数を持つ場合，送信元 $s_{x}$ を, 観測対象 $t_{k}$ に割り当て可能なセンサの集合 $v_{t_{k}} . s_{-} l i s t$ に追加する．さらに，メッセージ own_status を生成す る.own_status は, 観測対象 $t_{k}$ に関する new_target の送信元である，センサ $s_{x}$ に送信される

メッセージ own_status を受信したセンサ $s_{i}$ は，图 8 の 24-28 行目に示される処理で, 送信元 $s_{x}$ を観測対象 $t_{k}$ を割り当てることが可能なセンサの集合に追加する．

センサ $s_{i}$ か観測対象 $t_{j}$ を観測することが不可能になっ たとき, 図 8の 8-10行目に示される処理で, 観測対象 $t_{j}$ に関する変数を削除し，観測対象 $t_{j}$ に関するメッセージ lost_target を生成する.このメッセージは, $v_{t_{j}} . s \_l i s t に$ 含まれるセンサ , すなわち観測対象 $t_{j}$ に割り当て可能な センサに送信される .

メッセージ lost_target を受信したセンサは, 图 8 の 19-23 行目に示される処理で, 対応する観測対象 $t_{k}$ に関 する変数を持っていた場合に， $v_{t_{k} . s_{-} l i s t}$ から送信元 $s_{x}$ を 削除する .

\section{$\S 2$ 割り当ての状態を保持する状態表の生成}

観測対象へのセンサの割り当ての状態は, 状態表とし て表される.各センサは，観測対象ごとに状態表を保持 する. 各状態表は, 弚の観測対象に割り当て可能なセン サの情報を含む . 状態表に関する概念図を図 9 に示す . 状 態表の生成は，各観測対象のリーダーによる場合と，各 観測対象を観測可能なセンサによる場合がある .

ある時刻の問題の解が得られたときは, 图 9(a) で示す ように，観測対象のリーダーが状態表を生成する。図 8 の36-41 行目に示される処理で, 観測対象 $t_{\text {own }}$ に関す るリーダー $s_{i}$ は観測対象 $t_{\text {own }}$ に関する状態表を生成し， メッセージ own_table を生成する .このメッセージには，
観測対象 $t_{\text {own }}$ に関する状態表の情報が含まれる .

各観測対象 $t_{j}$ のリーダーは他のリーダーと情報を交 換し， $t_{j}$ にどのセンサを割り当てるかを決定する．弚の ため, $t_{j}$ のリーダーは $t_{j}$ に割り当て可能なセンサの情 報を得ることができ，弚の情報を用いて $t_{j}$ に関する状態 表を生成する．すなわち，リーダーが生成する状態表は， 他のリーダーから得られた変数值と自身の变数值に基づ く (図 9(a)のa). 乥して, メッセージ own_table が, 観 測対象 $t_{j}$ に割り当て可能なセンサに送信される (図 9(a) のb) . own_tableを受信したセンサは, 图 8 の 29-33 行 目に示される処理で, 対応する観測対象の状態表を更新 する .

問題が変化し, 観測対象に割り当て可能なセンサの集 合か変化したときは, 図 9(b)に示すように, 各センサが， 他のセンサと情報を交換しつつ，状態表を生成する . 新 たに観測対象 $t_{j}$ に割り当て可能になったセンサ $s_{i}$ は, 図 8 の 4-7 行目に示される処理で, 観測対象 $t_{j}$ に関する変 数を生成し， $t_{j}$ に関するメッセージnew_target を生成 する . new_target には観測対象 $t_{j}$ 対するセンサ $s_{i}$ の割

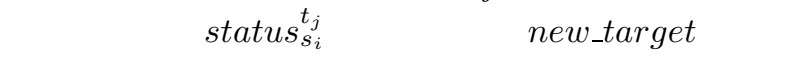
述の $S_{l}$ すなわち，リーダー選出層において制約て関係す る可能性のあるセンサに送信される (図 9(b) のa) .

観測対象 $t_{k}$ に関するnew_target を受信したセンサ $s_{i}$ は, 図 8 の13-18 行目に示される処理で, $t_{k}$ に関す る状態表に送信元 $s_{x}$ を追加し, メッセージ own_status を生成する．このメッセージには観測対象 $t_{k}$ に関する $s_{i}$ の割り当ての状態 status $_{s_{i}}^{t_{k}}$ が含まれる . メッセージ own_status はメッセージnew_target の送信元であるセ ンサ $s_{i}$ に送信される (図 9(b) のb) .

センサ $s_{i}$ か観測対象 $t_{j}$ を観測することが不可能にな り，観測対象 $t_{j}$ に割り当て可能なセンサの集合からセン サ $s_{i}$ が削除されるとき, 図 8 の 8-10 行目に示される処 理で, $t_{j}$ に関するメッセージ lost_target が生成される . このメッセージは $v_{t_{j}} . s \_l i s t$ に含まれるセンサに送信さ れる。

観測対象 $t_{k}$ に関するメッセージ lost_target を受信し たセンサは, 図 8の19-23 行目に示される処理で, $t_{k} に$ 関する状態表から送信元 $s_{x}$ を削除する。

各観測対象に割り当て可能なセンサが状態表を作成す る場合も, 状態表に関するメッセージは, 变数の生成や 削除の場合と同樣のセンサ間で送受される．また，これ らの処理は変数の生成や削除に付随してを行われる.

5.3 観測対象に割り 当てられたセンサの組み合わせの 変化の抑制

観測対象へのセンサの割り当ての変化を抑制するため に, リーダー選出層に 2 種類, 資源割り当て問題解決層 に 1 種類の緩和可能な制約を導入する.これらの制約で は, 先述の状態表を用いる . 


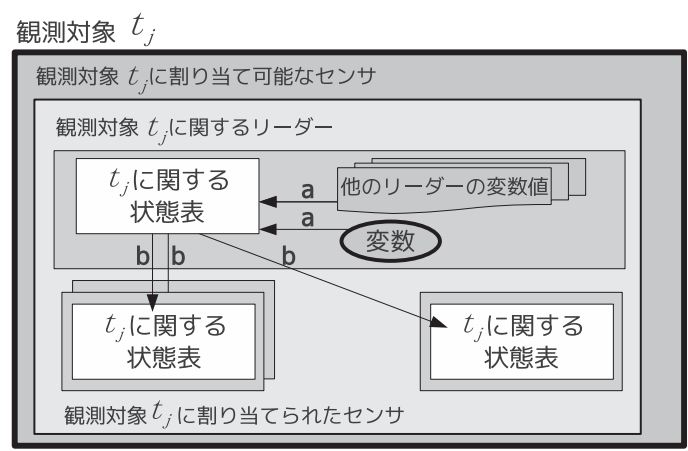

(a) リーダーが作成する場合

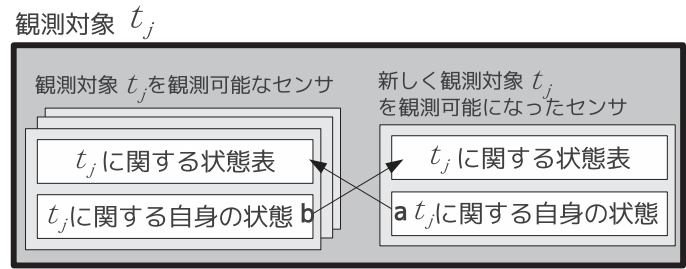

(b) 各センサが作成する場合

図 9 状態表の作成

$\S 1$ リーダーを同じグループから再選出するための制約 観測対象に対するグループの構造およびセンサの割り 当ての変化を抑制するために, 問題変化後も, 変化前と同 じセンサをリーダーとして選出する. 観測対象 $t_{j}$ のリー ダーであったセンサが $t_{j}$ に割り当て可能ではなくなった 場合は, $t_{j}$ のグループに属する他のセンサをリーダーに 選出する。

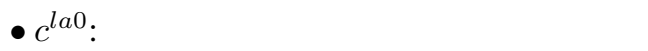

問題変化前に観測対象 $t_{j}$ に関するリーダーであった センサを, 变化後も $t_{j}$ にのリーダーとするための制 約である. 問題変化前と変化後で, リーダ一選出層 における変数值が異なる場合に, この制約は違反と なる.制約 $c^{l a 0}$ に対する評価関数 $f_{c} c^{l a 0}$ は式 (12)の ように表される.ただし $w^{c^{l a 0}}$ は制約のコスト值を 示す定数值である. $p r e_{t_{j}}^{s_{i}}$ は観測対象 $t_{j}$ の配置か湾 わる前のリーダーを表す。

$f_{c^{l a 0}\left(\operatorname{pre}_{t_{j}}^{s_{i}}, x_{t_{j}}^{s_{i}}\right)}= \begin{cases}w^{c^{l a 0}} & \operatorname{pre}_{t_{j}}^{s_{i}} \neq x_{t_{j}}^{s_{i}} \\ 0 & \text { otherwise }\end{cases}$

例外として, 問題変化前に観測対象 $t_{j}$ にリーダー が選出されなかった場合と, 問題変化前の $t_{j}$ のリー ダーが変化後の $t_{j}$ に割り当て不可能な場合は制約違 反としない .

・ $c^{l a 1}$ :同じグループに属するセンサからリーダーを選 出するための制約

観測対象 $t_{j}$ に関するグループに属するセンサの中 から観測対象 $t_{j}$ のリーダーを選出するための制約で ある. 観測対象 $t_{j}$ に関するグループに属するセンサ がリーダーに選出されないとき，この制約は違反と なる. 制約 $c^{l a 1}$ に対する評価関数 $f_{c^{l a 1}}$ は式 (13)の
ように表される

$f_{c^{l a 1}\left(x_{t_{j}}^{s_{i}}\right)}= \begin{cases}0 & x_{t_{j}}^{s_{i}} \text { is } t_{j} \text { member } \\ w_{0}^{c^{l a 1}} & x_{t_{j}}^{s_{i}} \text { is New or Free } \\ w_{1}^{c^{l a 1}} & x_{t_{j}}^{s_{i}} \text { is Other_member }\end{cases}$

$\S 2$ 観測対象に割り当てられたセンサの組み合わせの変 化を抑制するための制約

観測対象へのセンサの割り当ての変化を抑制するため の制約を，資源割り当て問題解決層にも導入する.

- $c^{a a 0}$ :観測対象に割り当てられたセンサの組み合わせ の変化を抑制するための制約

この制約は次の 2 つ場合に違反となる

。観測対象 $t_{j}$ に割り当てられていたセンサが，もは や $t_{j}$ に割り当てられない場合

。観測対象 $t_{j}$ に, $t_{j}$ 以外の観測対象に割り当てられ

ていたセンサを割り当てる場合

制約 $c^{a a 0}$ に対する評価関数 $f_{c^{a a 0}}$ は式 (14) のように 表される.式 (14) では観測対象 $t_{j}$ の $k$ 番目の割り 当て可能なセンサを $s_{t_{j}}^{k}$ と示す.また , $w^{c^{a a 0}}$ は制約 のコスト值を示す定数值である .

$$
\begin{aligned}
& f_{c^{a a 0}\left(x_{t_{j}}\right)}= \\
& \begin{cases}w_{0}^{c^{a a 0}} & s_{t_{j}}^{k} \text { is } t_{j} \text { _member } \wedge s_{t_{j}}^{k} \notin x_{t_{j}} \\
w_{1}^{c^{a a 0}} & s_{t_{j}}^{k} \text { is Other_member } \wedge s_{t_{j}}^{k} \in x_{t_{j}}\end{cases}
\end{aligned}
$$

6. 評価

$3 \cdot 2$ 節で示した STAV を用いる手法と，4 章で示した 2 階層からなる形式化を用いる提案手法を比較し，提案手 法の有効性を評価した．また， 5 章で提案した，問題が 変化する際のセンサの割り当ての変化を抑制する手法も 評価した . 各問題には解法としてDSTS を適用した .た だし, 明確な終了条件の無いDSTS では準最適解が $1 つ$ に決定しない，乥こで，6·2節に後述するように，DSTS

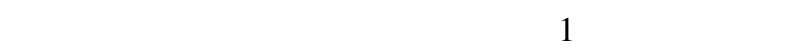
に調整した . 評価した手法は次のとおりである.

-STAV : $3 \cdot 2$ 節で示した形式化を用いる手法

-LYR : 4 章で示した 2 つの階層からなる形式化を用 いる手法

・LYR+ : センサの割り当ての変化を抑制するための 制約を，LYR のリーダー選出層にのみ加えた手法

-LYR++ : センサの割り当ての変化を抑制する制約す べてを，LYR の2つの階層产れ攵れに加えた手法 評価のために , シミュレーションによる実験を行った . シミュレーションでは, 次の処理が反復される .

(1) 例題の設定に従って観測対象の配置を更新する.た だし，観測対象の移動は，毎回ではなく，例題のパ ラメータで決められた間隔で起きる

（2）各エージェントはメッセージを受信して, 局所処 理を行う。 
（3）各エージェントは必要に応じてメッセージを他の エージェントに送信する

この処理の 1 回を 1 サイクルと呼ぶ氵

各問題の観測対象の数は 5 とし, 制約網が単一連結成 分となるように配置した . センサ網のグリッド数は観測 対象の配置を制限しないよう十分に大きくした . 各観測 対象は隣接する 4 つセンサで観測可能であるが，いず れかの観測対象を観測可能なセンサ数の合計は観測対象

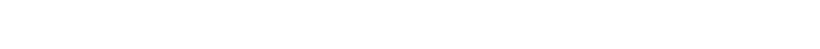
れ約 $13,12 ， 15$ であった。

動的な問題における变化として , 500 サイクルが経過 した時点で一つの観測対象を移動した . 移動する観測対 象は, これまで存在していた区画と隣接しかつ観測対象 が無かった区画に移るものとした .これはグリッドを用 いたモデルの制限下で, 現実に近い観測対象の移動を模 倣すること意図している．ただし，問題の規模を維持す るために, 上記の制約網を単一連結成分とする制限を課 した .

問題の変化は本来は継続的な時系列であるが, 本研究

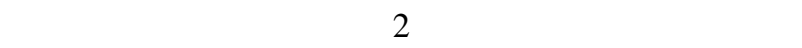
いる. 弚こで, 最小の単位である 2 つ問題からなる系 列を評価に用いた . また，2つの問題のうち変化前の問 題は光れ以前の問題を持たないため, 動的な問題に関す る制約が無い場合と見なすことができる.問題か湾化し たとき，変化前の問題の解を保持した状態で次の問題を 解き始めるものとした . 各解法を適用した結果は, 変化 前と変化後の問題乥れ光れに区別して評価した . 問題が 変化するまでの 500 サイクル以内に解を得られかった試 行は, 500 サイクルを要したものとし，弚の他の評価に は含めない .

上述の問題の各パラメータは, 提案手法の特性の評価 に適する範囲のものを，予備実験により決定した . 問題 ごとに 20 個の例題を用い，さらに各例題ごとに 1000 回 の試行の結果を平均した . 評価した項目は次のとおりで ある

・シミュレータが全体のコスト值を集計し解を得たこ とを検知するまでのサイクル数

・1つの観測対象に割り当てられたセンサの数

・観測対象に割り当てられたセンサを抑制するための 制約 $c^{a a 0}$ の違反の個数

\subsection{DSTS のパラメータ}

DSTS のパラメータを表 1 に示す .これらの值は，予 備実験により，解のコスト值が小さくなるものを設定し た・また，各制約の重み(コスト值)を表 2 に示す．緩和 不可能な制約の重みは比較的大きくした．また，制約の 数を考慮して，表 2 の值 100 および 200 のように緩和不 可能な制約の重みを変えた。緩和可能な制約 $c^{S T 0}$ およ び $c^{A 0}$ の重みは，割り当てられたセンサの数が少なくな るほど大きくなるようにした . 提案手法のリーダー選出
における緩和可能な制約の重みでは, 各観測対象に割り 当て可能なセンサ数の確保よりも，できるだけ全ての観 測対象にリーダーを選出する事を意図して,$c^{L 0} に c^{L 3}$ よりも大きい値を設定した .

観測対象に割り当てられたセンサの組み合わせの変化 を抑制するための制約の重みを表 3 に示す .これらの制 約は緩和可能であるが，予備実験では小さな值では効果 がなかったため $c^{l a 0}$ と $c^{l a 1}$ の一部に大きな值を設定した .

\subsection{DSTS の変更}

本論文では，提案手法とSTAV を用いる手法が，弚れ

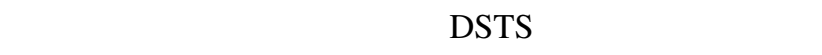
先述のように解を 1 つに決定するための簡単なルールを DSTS に加えた . 調整と変更点を以下に示す .

探索する解の範囲に関する調整:

確率 $p_{1}$ に従って変数值を変更する条件を各手法ごと に調整した . 提案手法のリーダー選出層では, ”改善量 $\Delta>0$ ”の場合に確率 $p_{1}$ に従って変数值を変更する.STAV を用いる手法と, 提案手法の資源割り当て問題解決層で は, ”改善量 $\Delta \geq 0$ ”の場合に確率 $p_{1}$ に従って変数值を変 更する.これらの違いは, 比較的值域の広い問題では解 を探索する範囲を広くすることにより，局所解から脱出 しやすくすることを意図する .

短時間で解に到達するための変更点:

確率 $p_{2}$ に従って変数值を変更する条件である，”自身 に制約違反か残っている場合”を置き換える.新たな条件 は，”自身が緩和不可能な制約に違反が残っている場合” である.この条件は提案手法と STAV を用いる手法のす べてに適用する．これにより，緩和不可能な制約を全て 満たしていた場合は, コスト值の改善量が負であれば変 数值か変更されなくなる .

解を 1 つに決定するためのルール:

確率 $p_{1}$ に従って変数值を変更する条件を”改善量 $\Delta \geq$ 0”とすると, 解が 1 つに決定しない .これは, 同じコス 卜值の解が複数ある場合に, どちらかに決定する基準が 無いことによる．乥こで，STAV を用いる手法と，提案 手法の資源割り当て問題解決層では, 緩和不可能な制約 を全て充足しているときは，次の条件を用いる．すなわ ち, ”改善量 $\Delta>0$ ”であれば, 確率 $p_{1}$ に従って変数值 を変更する .このようにすれば，緩和不可能な制約が全 て満足されるとき, 同じコスト值の解が存在していても， 変数値は変更されない．

\section{$6 \cdot 3$ 結 果}

\section{$\S 1$ 解を得るまでのサイクル数の比較}

解を得るまでに要したサイクル数を图 10 に示す. 問題 変化前におけるLYRでは, 解を得るまでのサイクル数は 約 27 サイクルであり，STAV の約 168 サイクルと比較し て約 84 \%少ない. また，他の提案手法 LYR+,LYR++も， 解を得るまでのサイクル数は LYR と同程度であり, 提案 
表 2 制約の重み 1

表 1 DSTS のパラメータ

表 1 DSTS のパラメータ
\begin{tabular}{|c|c|c|c|}
\hline & $p_{1}$ & $p_{2}$ & tabu-period \\
\hline \hline STAV & 0.8 & 0.4 & 1 \\
\hline LYR & & & \\
リーダー選出 & 0.9 & 0.3 & 2 \\
割り当て問題 & 0.7 & 0.2 & 1 \\
\hline
\end{tabular}

\begin{tabular}{|c|c|c|c|c|c|}
\hline \multirow[t]{2}{*}{ STAV } & & \multicolumn{4}{|c|}{ LYR } \\
\hline & & \multicolumn{2}{|c|}{ リーダー選出 } & \multicolumn{2}{|c|}{ 割り当て問題 } \\
\hline \multirow{3}{*}{$c^{S T 0}$} & $w_{0}^{c^{S T 0}}=15$ & $\overline{c^{L 0}}$ & $w^{c^{L 0}}=10$ & \multirow{3}{*}{$c^{A 0}$} & \multirow{3}{*}{$\begin{array}{l}w_{0}^{c^{A 0}}=15 \\
w_{1}^{c^{A 0}}=5 \\
w_{2}^{c^{A 0}}=1\end{array}$} \\
\hline & $w_{1}^{c^{S T 0}}=5$ & $c^{L 1}$ & $w^{c L 1}=200$ & & \\
\hline & $w_{2}^{c^{S T 0}}=1$ & $\overline{c^{L 2}}$ & $w^{c^{L 2}}=100$ & & \\
\hline$c^{S T 1}$ & $w^{c^{S T 1}}=200$ & \multirow[t]{2}{*}{$c^{L 3}$} & \multirow[t]{2}{*}{$w^{c^{L 3}}=1$} & \multirow[t]{2}{*}{$c^{A 1}$} & \multirow[t]{2}{*}{$w^{c^{A I}}=200$} \\
\hline$\overline{c^{S T 2}}$ & $w^{c^{S T z}}=100$ & & & & \\
\hline
\end{tabular}

表 3 制約の重み 2

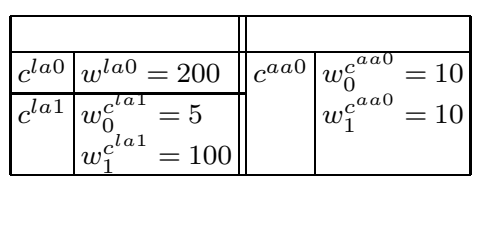

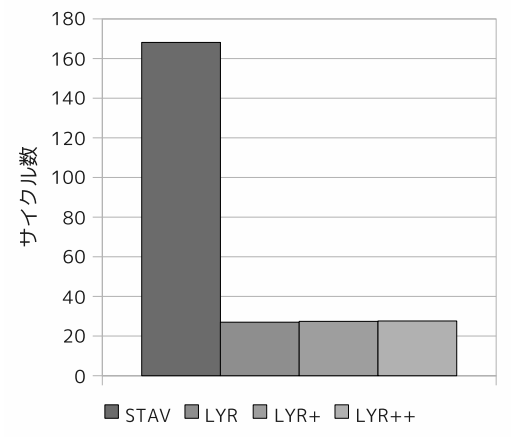

(a) 問題変化前

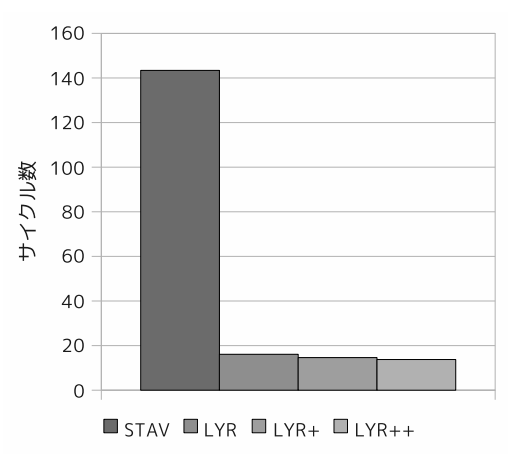

(b) 問題変化後

図 10 サイクル数の比較

手法ではより少ないサイクル数で準最適解を得た .これ は問題を $2 つ の$ 階層に分割したことで, 問題の複雑さが 緩和された結果であると考えられる.また，图 10(a) と 图 10(b) を比較すると, 問題変化後では, STAV は 140 サイクル程度, LYR,LYR+および LYR++は 20 サイクル より少なく，いずれも問題変化前より少ないサイクル数 て解が得られた .これは, 部分的に解を得ている状態か ら解探索を始めるためであると考えられる．また, 問題 変化後における提案手法の比較では, 観測対象へのセン サの割り当てを抑制するLYR+，LYR++ではLYR より もわずかにサイクル数が少ない . これは各手法における 探索空間が異なることによると考えらえる．弚の差異は 顕著ではないが, 制約が最も多く局所解の選択の余地が 少ないLYR++がより早く収束する傾向がみられる．

$\S 2$ 観測対象に割り当てられたセンサの数に関する評価

割り当てられたセンサ数ごとに集計した観測対象数を 表 4 に示す. 例えば, 表 4 の問題変化前のSTAV では, 3
表 4 割り当てられたセンサ数ごとに集計した観測対象数

\begin{tabular}{|c|c|c|c|c|c|c|c|c|c|c|}
\hline & \multicolumn{5}{|c|}{ 問題変化前 } & \multicolumn{5}{|c|}{ 問題変化後 } \\
\hline センサの数 & 0 & 1 & 2 & 3 & 4 & 0 & 1 & 2 & 3 & 4 \\
\hline STAV & 0.00 & 0.20 & 2.32 & 2.43 & 0.04 & 0.00 & 0.21 & 2.58 & 2.17 & 0.04 \\
\hline LYR & 0.00 & 0.48 & 1.69 & 2.14 & 0.70 & 0.01 & 0.55 & 1.75 & 2.12 & 0.57 \\
\hline LYR+ & 0.00 & 0.48 & 1.69 & 2.13 & 0.70 & 0.01 & 0.54 & 1.71 & 2.15 & 0.56 \\
\hline LYR++ & 0.00 & 0.48 & 1.68 & 2.13 & 0.70 & 0.01 & 0.52 & 1.71 & 2.07 & 0.60 \\
\hline
\end{tabular}

個のセンサが割り当てられた観測対象の数は平均で 2.43 である.なお，いずれかの観測対象に割り当られたセン サの数の合計はいずれの手法でも 12 から 13 程度とほぼ 同数であり, 観測対象を観測可能なセンサはほぼ全てが いずれかの観測対象に割り当られた . したがって, 表 4 は観測対象に割り当てられたセンサの数の分布を反映し ている.いずれの手法においても，資源割り当てに関す る制約において意図したとおり，3 個のセンサか割り当 てられた観測対象の数が多く, 次に 2 個のセンサか割り 当てられた観測対象の数が多い.

兴の一方で, 提案手法LYR, LYR+およびLYR++では, 3 および 2 個のセンサか割り当てられた観測対象の数が， STAVよりも少ない, 弚の代わりに, 提案手法では, 0,1 および 4 個のセンサか割り当てられた観測対象の数が比 較的多い.すなわち, 観測対象へのセンサの割り当てに はある程度の不公平性がある. この原因として, 各観測 対象に割り当てることが可能なセンサの数に不均衡が生 じることが挙げられる

提案手法では，ある観測対象に対するリーダーは，必 ずその観測対象を観測するように割り当てられる.ある 観測対象 $t_{j}$ を観測可能なセンサが付近の他の観測対象の リーダとなる場合は, $t_{j}$ に割り当てることが可能なセン サの数は少なくなる. また, 各リーダーが選出されるタ イミングは異なる場合がある. 光のような場合, 早い段 階で選出されたリーダーは, 弚の時点で割り当てが可能 なセンサを他のリーダーよりも先に割り当てることがで きる. 光のため, 後から選出されたリーダーでは, 自身 の観測対象に割り当てられるセンサが少なくなる場合が ある.このような不公平性は, 提案手法における探索の 即応性と解の精度のトレードオフといえる。

問題が変化する前後についての結果の差異は, 变化前 の問題の解を引き継いでいることおよび, LYR+,LYR++ では割り当ての変化を抑制していることに影響されたと 考えられるが, 全体的に顕著な傾向は見られなかった . 割 り当ての変更が最も制限されるLYR++では, 変化後の問 


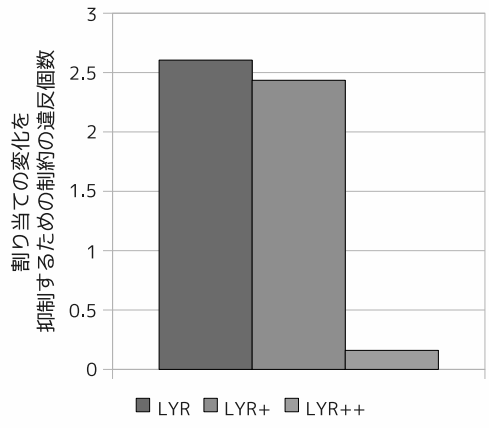

図 11 観測対象に割り当てられたセンサの組み合わせの変化を抑 制するための制約の違反の個数

題において , 十分な数である 3 個のセンサを割り当てら れた対象の数が 2.07 であり比較的少ない .

$\S 3$ 観測対象に割り当てられたセンサの組み合わせの変 化に関する評価

観測対象へのセンサの割り当ての変化を抑制する制約 $c^{a a 0}$ の違反の個数を図 11 に示す.ただし，LYR と LYR++ ではこの制約を用いないため，解から計算した換算値を 示す . 2 つの問題の階層において観測対象へのセンサの

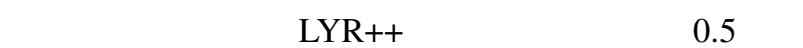
少なく, 2 より多い他の 2 手法よりも割り当ての変化が 顕著に抑制されている。リーダー選出層でのみ割り当て の変化を抑制する LYR+は, LYRよりは違反の個数が少 ない . LYR+では, 問題変化後のリーダーか問題変化前と 同一か, 問題変化前のグループから再選出された場合に， 少くても 1 個のセンサが問題变化後も同一の観測対象に 割り当てられる.これにより観測対象へのセンサの割り 当ての変化を抑制する効果が得らたものと考えられる.

\section{$\S 4$ 考 察}

提案手法では，2 つの階層からなる形式化と解法の効 果により,準最適解を得るまでのサイクル数は 20 程度で あり，従来手法の 170 程度よりも少ない(図 10(a)). 光 の一方で, 各観測対象に割り当てられたセンサの数には 不均衡が生じる．これは提案手法のトレードオフにおけ る欠点といえる．しかし，短時間のリアルタイム性を重 視する観測システムでは，このようなトレードオフを許 容できる場合があると考えられる．仮に，本手法を 1 サ イクルの実行時間が $10 \mathrm{~ms}$ となるように実装できるもの とし， $1.2 \mathrm{~m} / \mathrm{s}$ で移動する人物を観測する場合，従来手法 では解を得るまでに $1.7 \mathrm{~s}$ 程度を要し観測対象は $2 \mathrm{~m}$ 程度 移動する．これに対し，提案手法は $200 \mathrm{~ms}$ 程度を要し観 測対象は約 $0.25 \mathrm{~m}$ 移動する.この程度の差異が有用な場 合はありうると考える

また，本実験では実験時間の制限のため，特に十数台 程度の視野制御可能なセンサの協調動作を想定した実験 を行ったが, 制約網がより大規模になる場合は, 必要なサ イクル数はより増加すると予想される．弚の一方で, 制 約網の規模は観測対象の配置に依存する．観測対象か密
集していない場合は複数の制約網が構成され，光れらが 独立して並行に解かれることになる．この意味で実際的 なスケーラビリティを得ることは可能であると考えられ る.より大規模なセンサ網を構成する場合は，ある数の センサごとに提案手法を適用し，弚れらをより上位の階 層で疎に結合するなどの拡張が考えられる .

観測対象の配置が変化する動的な問題において, 問題 の変化後では変化前よりも解を得るまでの平均サイクル 数が少ない，すなわち，以前の問題の情報を用いること でより短時間で解を得ている.これは, 部分的に解探索 が進んでいる状態から問題を解きはじめることによると 考えられる. 兴の一方で, 問題の変化後の方が観測対象 に割り当てられたセンサの数の不均衡は大きい．この原 因は, 解探索が進んでいる状態から問題を解くことによ り，局所解から脱出する機会が少なくなるためであると 考えられる．また，観測対象に割り当てられたセンサの 組み合わせの変化を抑制するための制約の効果は, 意図 したように得られている。

\section{7. ま と め}

本論文では，注視制御可能な自律的なセンサ群による 観測システムを想定し，乥の観測資源割当て問題に対し て, 分散制約最適化問題の枠組を適用した、特に, 問題を 2 つの比較的簡単な問題に分割し, 各層に対応する問題解 決処理系を，部分的にメッセージを交換しつつ連携させ て解を得る手法を提案した . 提案手法では観測対象に割 り当てられたセンサの数に不均衡が生じる.しかし，準 最適解を得るまでのサイクル数の削減の程度を考えれば， 特に短時間の実時間性を重視する用途によっては,この 不均衡か許容されうると考えられる。したがって，階層 的な分散制約最適化手法には一定の有用性があると考え る．また，観測対象の配置が変化する問題において，変 化前の問題の情報を用いることにより，観測対象に割り 当てられるセンサの組み合わせの変化を抑制するモデル も提案し，乥の効果が得られることを確認した。

より一般的なセンサ網のモデルへの適用，実システム における検証も今後の課題である .

\section{謝辞}

本研究の一部は科学研究費補助金 (基盤研究 C(一般), 課題番号 21500073) の助成による .

\section{$\diamond$ 参 考 文 献 $\diamond$}

[Ali 05] Ali, S., Koenig, S., and Tambe, M.: Preprocessing techniques for accelerating the DCOP algorithm ADOPT, in 4th International Joint Conference on Autonomous Agents and Multiagent Systems, pp. 1041-1048 (2005)

[Bejar 05] Bejar, R., Domshilak, C., Fernandez, C., Gomes, C., Krishnamachari, B., Selman, B., and Valls, M.: Sensor networks and distributed CSP, Artificial Intelligence, Vol. 161, No. 1-2 (2005) 
[Matsui 10] Matsui, T. and Matsuo, H.: A constraint based formalisation for distributed cooperative sensor resource allocation, International Journal of Intelligent Information and Database Systems, Vol. 4, No. 4, pp. 307-321 (2010)

[Modi 03a] Modi, P. J. and Ali, S. M.: Distributed Constraint Reasoning under Unreliable Communication, in Distributed Constraint Reasoning Workshop at 2nd International Joint Conference on Autonomous Agents and MultiAgent Systems (2003)

[Modi 03b] Modi, P. J., Shen, W., Tambe, M., and Yokoo, M.: An Asynchronous Complete Method for Distributed Constraint Optimization, in 2nd International joint Conference on Autonomous Agents and Multiagent Systems, pp. 161-168 (2003)

[Modi 05] Modi, P. J., Shen, W., Tambe, M., and Yokoo, M.: ADOPT: Asynchronous Distributed Constraint Optimization with Quality Guarantees, Artificial Intelligence, Vol. 161, No. 1-2, pp. 149-180 (2005)

[Petcu 05] Petcu, A. and Faltings, B.: A Scalable Method for Multiagent Constraint Optimization, in 19th International Joint Conference on Artificial Intelligence, pp. 266-271 (2005)

[Zhang 02] Zhang, W., Wang, O., and Wittenburg, L.: Distributed stochastic search for constraint satisfaction and optimization: Parallelism, phase transitions and performance, in AAAI Workshop on Probabilistic Approaches in Search, pp. 53-59 (2002)

[飯塚 07] 飯塚泰樹, 鈴木浩之, 竹内郁雄 : 分散制約充足問題のた めの Multi-agent Tabu Search 手法の効果, 電子情報通信学会論文 誌, Vol. J90-D, No. 9, pp. 2302-2313 (2007)

[浮田 05] 浮田宗伯 : 能動視覚エージェント群の密な情報交換に よる多数対象の実時間協調追跡, 電子情報通信学会論文誌, Vol. J88-D-I, No. 9, pp. 1438-1447 (2005)

\section{〔担当委員 : 山下 倫央〕}

2011 年 3 月 26 日 受理

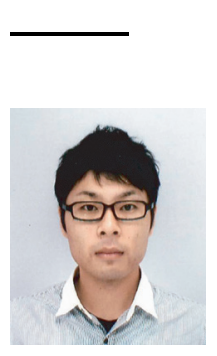

\section{者 紹}

太田 和宏

2009 年名古屋工業大学工学部情報工学科卒業 . 2011 年同 大学大学院工学研究科創成シミュレーション工学専攻修士 課程修了.マルチェージェントシステム, 分散システム等 に興味を持つ。

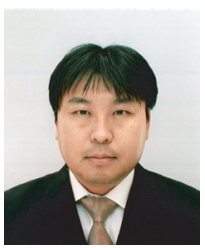

\section{松井 俊浩(正会員)}

1995 年名古屋工業大学電気情報工学科卒業. 1999 年同大 学大学院博士前期課程修了. 2006 年同博士後期課程修了. 同年名古屋工業大学情報基盤センター助手. 2007 年同助 教. 2011 年同准教授. 現在に至る.分散協調処理, マル チェージェントシステム, 分散制約最適化問題に関する研 究に従事. 博士 (工学). 電子情報通信学会, 情報処理学会, 各会員.

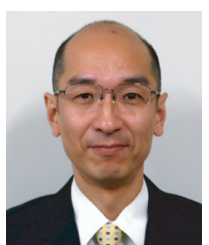

\section{松尾 啓志(正会員)}

1983 年名古屋工業大学情報工学科卒業. 1989 年同大学大 学院博士課程修了. 同年名古屋工業大学電気情報工学科助 手. 講師, 助教授を経て, 2003 年同大学院教授. 2006 年 情報基盤センターセンター長 (併任). 2011 年付属图書館 長. 現在に至る. 分散システムに関する研究に従事.工学 博士. 電子情報処理学会, 情報処理学会, IEEE 各会員. 